\title{
The Analysis about the Network Expansion of Enterprise Viral Marketing
}

\author{
Shourong Tang ${ }^{1}$ \\ ${ }^{1}$ Shanghai University of Engineering Science, Shanghai, China \\ Correspondence: Shourong Tang, Shanghai University of Engineering Science, Shanghai 201620, China. E-mail: \\ 1101297946@qq.com
}

Received: February 27, 2014

Accepted: March 15, $2014 \quad$ Online Published: May 4, 2014

doi:10.5430/jms.v5n2p49

URL: http://dx.doi.org/10.5430/jms.v5n2p49

\begin{abstract}
There are a lot of unexpected changes taking place in the online world. Viral marketing is a typical efficient network marketing method which births at the background of the Web2.0 era. It is high concerned with its clipping and comprehensive effect on society. Studying its mechanism, in addition to the spanking speed of the Internet, the rapid transmission method and the wide range of audience, it mostly depends on idiographic interactive involvement and relationship. This article mainly summarizes the concept of Viral Marketing, the similarity of enterprise Viral Marketing, the negative effect and the responsive tactics.
\end{abstract}

Keywords: viral marketing, network, innovation

Although the term "virus" was transformed from epidemiology to explain the ways in which internet users spread information, the viral of the nature is different from the viral of the Internet. The vast majority spread the virus unconsciously. The reason more and more enterprises are in love with viral marketing is while the users use their products, they also spread the products.

\section{A Successful Case about Internet Viral Marketing: Coca-Cola: A Lift for Talent Show}

In 2013, "China good voice" and "Happy Boys" and other talent shows are strongly welcomed, and how to use these shows to popularize themselves is a problem many companies are thinking about. Of course, the simplest and most conventional idea is generating closely connection with talent show by a large investment, such as advertising, sponsor and so on. For example JDB sponsored "China good voice" with 200 million yuan. But if there is zero input, are many enterprises only standing by? Of course the answer is "No". The performance of "Happy Boys" finals on the micro blogging Coca-Cola can explain everything. On that night, Coca-Cola issued two pieces of micro-blogging which are related to the game. The first is issued after reminiscence of Li Yuchun and Zhou Bichang with the content "That time and this time, there are too many differences, but fortunately the happy face is still young. 8 years in mind, we are still together". The theme is "Small Coca-Cola sees the world" with a picture. The second is issued at the end of the game, and with the Coca-Cola with Martian nickname metaphors the champion Hua Chenyu who is called "Martian". (Note 1)

The highlight of Coca-Cola "lift for talent show" is getting the marketing, social celebrities and popular events together flexibility, which stimulates the enthusiasm of the public with an extremely easy way, and realizes the volume spread. Coupled with the joking elements during the marketing, the virus power of Coca-Cola is overwhelming. You must know one truth that there is no entertainment if there is no virus. Not only the Internet is entertainment economy, but also is the attention economy. Without advertising, Coca-Cola can still show its ability by "Happy Boys" and micro blogging, and realize the perfect combination between itself and the talent show. With the platform of Micro-blogging Marketing, people can watch the game, at the same time they can brush micro-blogging, and then causes the "viral" forwarding. Facing such hot social events, no advertisement putting does not mean you have no marketing opportunity and does not mean you can’t advertise.

\section{Viral Marketing}

\subsection{The Concept of Viral Marketing}

Viral marketing is an information dissemination strategy, which can cheaply copy information to tell other audiences through public so as to expand its influence on customers in a spanking way. It is similar to "Word of Mouth" and 
"Relationship Marketing" only from the conceptual point of view. From deeper point of view, Viral Marketing integrates "Word of Mouth Marketing" and "Relationship Marketing" effectively, becoming a more powerful online marketing tool.

The traditional way of marketing is through advertising, so that customers accept product information passively. But with the increasing of the ads number, although marketing costs is rising, its effect is diminishing. While viral marketing attracts customers in an induced way, and provides consumers recreational activities which many people can participate in so it has been widely welcomed. Viral Marketing quickly finds other vulnerable crowd through consumers which are called " the owned media" and a low-cost spread. Also it enhances its brand visibility and reputation. The virus Viral Marketing spreads is "multi virus", rather than "single virus", and the virus source is not businesses, advertisers individual, but large users.

\subsection{The "Network Effect" of Viral Marketing}

There is an inherent interconnected need for information products, because the purpose people produce and use them is to collect and share information better. This satisfaction degree of the demand is closely related to the scale of the network. With the increasing of the user's number, all users may benefit from the network. In this case, the value of one product to a user depends on the amount of other users using the product, which is called Network Effect. The term was firstly used to describe the spread of the phenomenon about telephone on the early 20th century. In short, to people who have been using the telephone service, the more the number of people owning telephone, the bigger the value of each additional phone line will be. (Note 2)

In the case of two users, we have the communication path as Figure 1.

\begin{tabular}{ll}
\hline 1 & User $1 \rightarrow$ User 2 \\
2 & User $2 \rightarrow$ User 1
\end{tabular}

Figure 1

In the case of three users, we have the communication path as Figure 2

\begin{tabular}{lc}
\hline 1 & User $1 \rightarrow$ User 2 \\
2 & User $2 \rightarrow$ User 1 \\
3 & User $2 \rightarrow$ User 3 \\
4 & User $3 \rightarrow$ User 2 \\
5 & User $1 \rightarrow$ User 3 \\
6 & User $3 \rightarrow$ User 1 \\
\hline
\end{tabular}

Figure 2

A network with 5 users can bring 20 potential connections. A network with 20 users will create 380 possible connections. Thousands users will bring millions of connections. Precisely because of the large number of people using the network, and Smartphone most young people are playing, it is more convenient for Coca-Cola to market himself without any money. They transmit the micro-blogging of Coca-Cola to their friends, and their friends transmit it to another. It is hard to imagine his click rate, pageviews.

\section{The Generality of Enterprises Proceeding Successful Internet Viral Marketing}

$3.1 \mathrm{Web}$-based: The smooth negotiability of the Internet world is the important guarantee for them to stand out from traditional businesses.

3.2 Free: Users use the product freely. It may increase a variety of revenue sources (such as providing rechargeable advanced services) after absorbing a huge number of users.

3.3 The Feature of Spreading: Users will spread this product in order to achieve their interests and they will establish a good reputation for the product in the process to attract new users (Word of Mouth is often regarded as the best form of advertising). This means that the virus circulation product has its own spontaneously growing 
transmissibility.

3.4 Exponential Growth: As per user can attract more users to join in, viral marketing companies will form a completely different business development model from the normal typical business with linear growth pattern. The growth rate of normal business is often directly affected by marketing speed.

3.5 Adopted Quickly by the User: Face book attracted 50 percent of Harvard students at school in the first month when it was released. Skype was downloaded by 12 million users in 13 months. Hotmail had 30 million users within 30 months.

3.6 Viral Coefficient (the number of users new members brings): The number of users will realize exponential growth only in the case that the viral coefficient is greater than or equal to 1 . Once the viral coefficient is less than 1 , the network will not achieve its self-propagation.

3.7 Network Effect: The more the number of people using one product in the network, the more attractive people will join in this network.

3.8 Irreplaceable Point: Once the number of users exceeded the critical point, it can sustain growth even if the organizers do not do anything. The reason is that when people build a social network, they will naturally invite their friends, family, colleagues and like-minded strangers to sign up and join in it. And the new members will continue to invite more friends to join together.

These elements make a quick afloat and high-speed developmental enterprise, which can gain profit in a very short time.

\section{Three Innovations of Viral Marketing Network}

\subsection{Electronic Screen}

As an organizational innovative technology which can bring overturning impact on the industry, the rapid development of electronic screen system technology produces a very profound impact. In the macroscopic aspect, because the Internet has the functions of storing and organizing information, the internet itself is a kind of organizational innovative technologies. Electronic screen to be honest is the media for people to participate in viruses-like spreading model.

\subsection{Electronic Chip}

"Net book" is a new hardware which is explored by Intel. This mini PC with light weight and low price can be able to run some basic computer functions such as word, e-mail, and browse nets and so on. In addition, the new chip will also become the main driven equipment of GPS, electronic reading and tablet PC, etc.

\subsection{Ubiquitous Network Connections}

No matter who and where you are, you can move into the mobile information network, so that millions of Mimu (Cultural gene, the smallest unit of cultural transmission) can transfer from one screen to another. Entertainment, news, e-mail, text messaging and phone calls will run among various transceiver people at the speed of 100 kilometers per hour. With the carrier with a smart phone or other small mobile devices, all this work will achieve the greatest degree of spread of the virus.

\section{Negative Effects of Viral Marketing Network}

In any case that all information communicates, there certainly will be potential risks. The stronger the connectivity between each other, the more serious the dangerousness which the massive diffused information brings is. In real networks, the phenomenon which Viral Marketing is misused often appears. Much false, malicious information is spreaded widely through Viral Marketing model, which will have a huge negative impact on the community and the individual. Take the KFC as example. Due to the global coverage, on Face book, the account number of KFC is a large number plus account number from each country, which is a very complete layout .So that every country can publish the information which fit their account, and it is convenient for users to accept. It is also followed the mode "online-offline-online", with a secondary transmission of feedback. However, because of the extensive coverage, KFC also made a false decision on Face book. After Thailand earthquake on April 2012, KFC cracked a joke about the earthquake on Face book. It said "We hurry to home and pay close attention to the latest news about this earthquake, but do not forget to order a part of KFC which you like best." (Note 3) This event suffered intense attack immediately. A lot of Thai people were very angry at this thing. They thought that KFC was self-interest and insensitive and it made money through the disaster, which caused panic. One comment from Omelette network said that obviously, in this insecure environment and extreme panic emotion, people are badly in need of a number of 
fast-food to store, which is indeed a good opportunity for KFC in odder to improve their turnover greatly. However, they forgot one important point that compared with the lives of thousands of people, what's the meaning of money? Being aware of the serious situation, KFC had to remove the information and made an apology to public. Therefore, the connotative and comprehensive social impact in the process of Viral Marketing is also worth pondering. Business should take up some social responsibility to support the construction of socialist spiritual civilization and form a good competitive market environment in the process of marketing and pursuing the economic interests.

\section{Steps of Companies to Properly Implement Viral Marketing}

\subsection{Design Proposal}

Make an overall planning about Viral Marketing scheme and confirm their compliance with the basic idea of Viral Marketing and make sure it is of great value to users. In the Internet age, as long as consumers concern, the communication can be free and the development can be rapid.

\subsection{Design Information Sources and Communication Channels}

It is very effective to find an influential "opinion leader" to precede Viral Marketing. This "opinion leader" is knowledgeable, authoritative and he is able to guide the opinion of public. Then determine the channels of communication, no matter it is downloaded from the Internet, or transfer files directly between users, or a combination of these two forms.

\subsection{Release the Original Information}

When you publish original information, you should design it seriously. Original information should be posted on the place where users can find easily, and are willing to transfer, such as Micro-blogging, Micro-letters.

\subsection{Subsequent Tracking and Management}

Although the mode of transmission of Viral Marketing is consumer-oriented and relies mainly on self-propagation of the virus, it is not said that companies let it go after putting "virus" into market. Enterprises should monitor the range of "virus", the rate of growth of customer and so on. It is helpful for enterprise to find and solve problems timely, so that the Viral Marketing campaign can achieve better results if the enterprise makes subsequent tracking and monitoring to Viral Marketing campaign.

\section{Conclusion}

With the further development of the Internet, the applications of Viral Marketing are welcomed by more and more firms. In the implementation of Viral Marketing, enterprise should be combined with its own characteristics, and chooses an attractive topic to spread the "virus" on the network platform. In the implementation process of Viral Marketing strategies, company should choose marketing methods which suit their own station, in accordance with certain Viral Marketing steps and processes, combining with innovative promotional methods and channels to enable businesses and consumers to achieve win-win results.

\section{References}

Guo, Jing. (2013). Cyber Style and Viral Marketing. Shanghai Economy, (10).

Liu, Xiangyang. (2010). Research on Theoretical Foundation and Mechanism of Transmission of Viral Marketing.

Wang, Zhiying. Viral Marketing Risks Associated With the Harvest Counterparts. China Advertising.

\section{Notes}

Note 1. Coca-Cola: "A lift for talent show", Sales Market, 2013, (11)

Note 2. Adaml Denenbery, Viral Loop, 2013

Note 3. Survive on the society with KFC, Business Circles, 2013, (7) 